\title{
The Effects of Cooperative Learning on Self-Efficacy in an EFL Classroom
}

\author{
James Saunders-Wyndham \\ Kyoto Sangyo University \\ Eleanor Smith \\ Aichi University
}

The objective of this study was to determine whether incorporating cooperative learning approaches positively influences the perceived self-efficacy of learners taking part in a compulsory English language program at the university level. This study tested the hypothesis that implementation of strategies fostering language skill development through cooperative learning leads to an increase in student self-efficacy. Qualitative and quantitative methods were employed to investigate this hypothesis in treatment and contrast groups. Four aspects of self-efficacy were measured: mastery experience, vicarious experience, social persuasions, and physiological reactions. Increased scores in mastery experience were observed. The treatment group scores for vicarious experience increased at a statistically significant level, whereas the contrast group scores did not. Qualitative findings revealed that, although participant responses support an increase of self-efficacy, no consensus was given to identify which specific classroom factor was responsible for the increase. The results showed that neither group experienced a statistically significant increase in scores for the latter two scales of social persuasions and physiological reactions.

本研究は大学必修英語科目の授業において、学習者が感じる自己上達度に共同学習が良い 影響を与えるかの検証を行う。この研究では、学習者主体の共同学習では学習者自身の経験 を話し合い、活用することで学習者の英語能力についての自己効力感が上昇するという仮説 を設定する。仮説の検証に処置群と対照群に対して、質的と量的の両手法を用いて分析を実 施した。自己効力感の 4 側面である成功体験、代理学習、社会的説得、身体反応を測った。

https://doi.org/10.37546/JALTJJ42.2-2

JALT Journal, Vol. 42, No. 2, November 2020 
十分に言語知識を得ることができたと回答する「成功体験」の值の増加が確認された。処置 群においては、共同学習のパートナーの経験を自分も同様に感じる「代理（体験）学習」の 值の増加が統計上で有意差を示す一方、対照群にはその傾向は見られなかった。質的調査結 果から、参加者の回答は自己効力感の増加を裏付けるものの、増加の原因となった特定の教 室要因に関しては意見が分かれたことが分かった。処置群にも対照群にも「社会的説得」と 「身体反応」の值の増加は統計的な有意差となって表れなかった。

Keywords: autonomous learning; cooperative learning; EFL; self-efficacy; student-centred learning

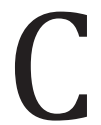

ooperative learning (CL) is defined by the instructional use of small work groups that optimise the learning process of their members (Johnson et al. 2013, cited in Johnson \& Johnson, 2014). It is perceived that individual participants benefit by aligning their goals with other group members (Johnson \& Johnson, 2014). Despite CL approaches gaining strong favour in countries such as Japan (Oxford, 2017; Sakui, 2007), traditional language teaching methodologies continue to prevail. This can be explained by specific sociocultural attitudes towards education and language learning. Williams and Andrade (2008) reported that a noteworthy sample of Japanese university students studying English considered the main sources of reported learner anxiety to be class output and open expression. Thanh et al. (2008) even argue that Western teaching principles are at odds in Asian sociocultural contexts. It is not yet clearly understood how learners from non-Western cultures react to $\mathrm{CL}$ approaches in a language learning environment.

Bandura (1977) outlined the concept of self-efficacy (SE), a component of social cognitive theory, as the belief or judgement of one's own ability to attain selected goals. The theory of SE has previously been employed in linguistic research to address the understanding of both student and teacher behaviour (Bandura \& Schunk, 1981; Hsieh \& Schallert, 2008; Magogwe \& Oliver, 2007; Pajares, 2003; Raoofi et al., 2012; Schunk, 1991; Wong, 2005; Yllmaz, 2010). SE becomes a prominent variable when detecting student reactions to a CL environment. By understanding how learner-perceived SE is affected by language learning environments, educators can better adjust teaching approaches to cater to the sociocultural needs of students. CL outcomes have been measured within the Asian and/or Japanese cultural context regarding academic outcomes (Thanh et al., 2008), motivation (Tan et al., 2007), learner anxiety (Yoshida et al., 2013), and implementation (Sugie, 1999). However, the importance of CL teaching approaches in relation to student-perceived SE is yet to be discussed. 


\section{Purpose}

This study addressed the following question: "To what degree is student SE influenced by CL strategies in an EFL classroom?" The research was conducted in classrooms at a private Japanese university in a compulsory EFL course. The study tested the hypothesis that implementation of strategies fostering language skill development through CL, such as group projects and task-based learning, in a strong communicative-language-learning environment lead to an increase in student SE.

\section{Cooperative Learning and Self-Efficacy Cooperative Learning and Self}

Built upon social interdependence theory (Johnson \& Johnson, 2009), the CL approach offers learners recurring opportunities to interact in an encouraging group environment with other students, thereby creating motivation to succeed on both an academic and social level (Chips, 1993; Madrid, 1993). Johnson and Johnson (2014) argued that, when individuals support the learning outcomes and well-being of others, those interpersonal relationships support positive images of self, most notably self-esteem and SE. This claim is supported by previous research in American contexts, where it was found that CL outcomes related to an increase in both self-esteem and SE (Johnson, 1979; Madden \& Slavin, 1983; Norem-Hebeisen \& Johnson, 1981; Oickle, 1980). The bulk of social interdependency theory and CL research was conducted in Western contexts between the 1970s and 1980s (Johnson \& Johnson, 2005), and thus greater insight into the relationship between CL and SE is arguably necessary.

\section{Cooperative Learning in the Japanese Context}

Johnson and Johnson (2005) maintained that, because cultures differ from one another, so do their definitions of cooperation and the conditions under which they are appropriate. The introduction of Western CL approaches in the Asian cultural context has been criticised as undermining traditional teaching approaches and even referred to as educational neocolonialism (Phuong-Mai et al., 2009). Phuong-Mai et al. (2005) contended that the cooperative class model is fundamentally incompatible with cultures harking from Confucian philosophical thought. Their research referred to numerous aspects (which, in principal, conflict with the CL model) in which abstractions such as power distance, collectivism, and uncertainty avoidance are pertinent. Japan ranks high in uncertainty avoidance and collectivism (Bergiel et al., 2012). Not 
only do students from strong uncertainty avoidance cultures heavily rely on teacher guidance, they could feel threatened or avoid teaching situations they perceive as unknown and avoid confrontations in order to save face (Hofstede et al., 2010). Thus, students in a collectivist culture may hesitate to speak up in situations that lack a central person of authority such as a teacher. Although CL has been established in Japanese educational settings, it can be argued that it is yet to take a serious foothold in CLT (communicative language teaching) classrooms due to cultural incompatibility. Therefore, more research is needed to help culturally integrate CL as a valid teaching approach.

\section{Self-Efficacy}

SE becomes a prominent variable when detecting student behaviour or beliefs in educational settings. Zimmerman and Cleary (2005) argued that SE is less about individual judgements of physical or personal attributes, but rather about personally held beliefs of what one can achieve. Bandura (1997) expressed the importance of SE in the following terms: "Self-belief does not necessarily ensure success, but self-disbelief assuredly spawns failure" (p. 77). Thus, high levels of SE should be perceived as precursors to positive learner development and a key advantage to the construction of a well-balanced class. SE comprises three achievement goals: mastery, performance-approach, and performance-avoidance (Liem et al., 2008). Mastery goals are described as the development of one's perceived competence; performance-approach goals are an individual's perceived ability or competence in relation to peers or others; performance-avoidance goals are one's own avoidance of personal failure to elude perceived incompetence by others (Diseth, 2011). According to a review of over 90 studies by Linnenbrink-Garcia et al. (2008), mastery goals were described as having a positive relationship to academic achievement in $40 \%$ of the reported effects, with a similar positive effect for performance-approach (Bjørnebekk et al., 2013). SE and goal orientations can assist in the prediction of achievement-related outcomes, for example, deep and/or surface learning strategies and examination grade (Diseth, 2011; Liem et al., 2008). Personal agency is influenced by the belief in one's effectiveness in performing specific tasks as well as by actual skill (Zimmerman \& Cleary, 2005). Increasing SE can aid student development by unlocking learner potential.

\section{Self-Efficacy in Language Education}

Coronado-Aliegro (2007) asserts that despite past SE research being applied to educational settings, few researchers have observed how educators can en- 
hance student SE in a foreign language classroom. Although research concerning the concept of self has been conducted within the Japanese or Asia educational context (Kimura et al., 2001; Ning \& Hornby, 2014; Tan et al., 2007; Ueki \& Takeuchi, 2012; Williams \& Andrade, 2008; Yashima, 2002), these studies neither offer significant insight nor mark any substantial contribution to the study of SE. Existing research appears to overlook SE as a principal theme of inquiry. A literature review by Raoofi et al. (2012) analysed 32 investigations that used Bandura's definition of SE as either a dependent or independent variable in the field of L2 learning. The authors reached the conclusion that the studies suffered numerous limitations in their research methods, which prevented them from producing substantial results. One such limitation has been directly addressed by the research methods in this paper: The dependence on quantitative data left open the necessity for further understanding through the collection of qualitative data.

Despite Raoofi et al.'s (2012) assertions of limitations in research methods, findings of select authors have yielded noteworthy contributions to this field of enquiry, arguing that increased SE results in positive language learning outcomes. Anyadubalu (2010) ascertained through quantitative inquiry that SE correlated with low anxiety in the language learning forum. Zheng et al. (2009) concurred that fostering positive attitudes (defined as students feeling relaxed and confident) towards freedom of communication whilst simultaneously shifting away from memorised rhetoric benefitted students in the long term. Tilfarlioglu and Ciftci (2011) employed quantitative methods to determine that autonomy and academic success enjoy a strong positive correlation, stating that "the more self-efficacious and autonomous learners are, the more successful they become in learning a language" (p. 1289). Research findings such as these highlight the potential significance of SE as guiding and attaining realistic student goals in educational settings.

\section{Methodology}

\section{Participants}

The participants were 1st year science and arts majors (aged 18-19) attending a private Japanese university, with at least six years of previous formal English education. Although none were English majors, they were enrolled in a mandatory elementary level English communication course. They showed low-level English language comprehension and fluency and exhibited behaviour that suggested low motivation to study English. All participants followed the same textbook and curriculum. Quantitative data from 90 participants were used from the first round of questionnaires at 
the beginning of the spring semester ( 44 in the treatment group, and 46 in the contrast group). This decreased to 83 participants' data being used in a second round of questionnaires (at the end of the fall semester) due to seven absences in the contrast group. Data from 16 participants (eight from each group) were selected for qualitative analysis (interviews). Students were approached based on their availability and willingness to participate in interviews. Interviews were conducted in the final week of the fall semester. All data were collected using convenience sampling (Dörnyei, 2007) due to its practical nature considering time restraints on students.

\section{Instruments}

To obtain quantitative data, a 30-item questionnaire (see Appendix A) comprised of four scales was designed to measure SE. Each item was a statement that required participants to rate their perceived ability on a numerical rating scale (as used by Bandura, 2006, p. 312) ranging from 0 ('impossible for me') to 100 ('absolutely possible for me'). The scales were Mastery Experience (ME; the belief in one's own ability to master a task), Vicarious Experience (VE; the belief in one's own ability from observing others), Social Persuasions (SP; the belief in one's own ability when receiving verbal encouragement from others), and Physiological Reactions (PR; the belief in one's own ability in potentially stressful situations).

Qualitative data were collected and analysed to obtain greater insight into learner perceptions. The purpose of each interview was to gain a deeper and more nuanced understanding of learner's opinions about their experience of the lessons, paying attention to the effect of collaboration and autonomy on their perceived ability to communicate in English. Questions (Appendix B) such as "How do you feel about your own English ability after your classmates do well in class?", "When working with your classmates in a group, did you feel positive about your English ability?", and "When you received support from a classmate, did you feel that your English ability could improve?" aimed to delve deeper into the scales that were used to measure various types of SE within the questionnaire. Excerpts from the interview transcripts protect participant anonymity by identifying eight individuals from the treatment group as T1-T8 and another eight individuals from the contrast group as C1-C8. The interviewer is identified as IR.

\section{Classroom Procedure}

Both contrast and treatment groups met once weekly with the teacher for a 90-minute class, covering two 15-week long semesters. For both groups, 
students were assessed on individual performance and participation. The contrast group was taught in a teacher-led learning environment, using Kagan's (1989) competitive structures model of whole-class question-answer as a theoretical guide. This is outlined in four main steps: 1) The teacher asks a question; 2) students who wish to respond raise their hands; 3) the teacher calls on one student; and 4) the student attempts to state the correct answer (Kagan, 1989, p. 12). Lesson plans rigidly followed the textbook, with one unit taught over 2 weeks. The 1st semester covered the first six units, while the 2 nd semester covered the final six units.

Adhering to the class structural outline, students were instructed to work independently and, on occasion, to participate in interactive communication practice with a partner. Although specific seating was not assigned, contrast group classes were required to sit in pairs. Most classes were teacher-centred, with the teacher eliciting responses from students in front of the whole class. Class assessment was comprised of in-class tests, presentations, and preestablished written homework.

The treatment group lessons were modelled on six CL elements: team formation, team building, class building, role assignment, processing (group discussion), and structures (workstations) (Kagan \& McGroarty, 1993). Consistent with the contrast group, one unit was taught over 2 weeks with the first six covered in the spring semester, and the final six in the fall semester. Students were tasked with forming themselves into groups of four to five members and were instructed to form groups consisting of new members at the start of each unit. A team leader for each group was chosen at the start of each unit by the group members. This person was responsible for reporting their progress and problems to the teacher, including reporting absent members of their group. This was allocated 10 minutes of class time. Three workstations were set up in the classroom: a textbook station (focussed on understanding and practising grammatical structures covered in the unit), a task-based activity station (focussed on completing topic-related tasks designed by the researchers), and a research-based activity station (focussed on finding, amalgamating, and presenting topic-related information either to the teacher or to the class in the final week of each unit). The teacher gave instructions for each station in the first 5 minutes of class, and allocated groups to each station. Students had 25 minutes to complete what was required of them before moving on to another station. The teacher was then free to address any issues as they surfaced and to visit each workstation to check on progress. Group members were encouraged to share contact details (using the social networking application, LINE). Participation, completion of tasks, and quality of work were parameters for assessment in this class. 


\section{Data Collection and Analysis}

The questionnaire was piloted to amend potential problems regarding explanation delivery, item comprehension, and consent-form issues. It was then administered to participants in Japanese at the start of the spring semester and again at the end of the fall semester, to gauge any changes in SE over the academic year. Instructions were given both verbally and in written Japanese. The process of administering, completing, and collecting the questionnaires took approximately 15 minutes per class. Japanese consent forms were explained, signed, and collected prior to administering the questionnaire. Participants were made aware that their choice to withdraw would not incur any consequences. Quantitative data were analysed in IBM SPSS Statistics (Version 26) by applying Paired-Samples $t$ tests and a oneway analysis of covariance (ANCOVA).

Upon receiving both written and verbal consent, 16 participants were interviewed in groups of four or five, in Japanese, and at a mutually convenient location and time during the final week of the fall semester. Each interview took approximately 20 minutes to complete. They were recorded using standard voice recorders before being translated into English by the authors (translations were conducted by the researchers and independently checked for accuracy by two other Japanese speakers who also speak English) and coded to identify themes pertinent to the objectives of the study.

\section{Results and Discussion}

\section{Quantitative Data Analysis}

Reliability checks revealed each scale had a high level of internal consistency, as determined by Cronbach's alpha. Reliability scores of .855, .925, .863 , and .858 were recorded for ME, VE, SP, and PR respectively. Scores for each scale were normally distributed as assessed by the Shapiro-Wilk test ( $p=.499, .068, .312$, and .278 for ME, VE, SP, and PR respectively) and visual assessment of histograms.

\section{Descriptive Statistics}

Table 1 compares the means between the two groups over both semesters. It is evident that the contrast group began the year with higher mean scores for each scale than the treatment group, and this remained unchanged in the fall semester. 
Table 1: Descriptive Statistics for Treatment and Contrast Groups for Spring and Fall Semesters

\begin{tabular}{|c|c|c|c|c|}
\hline \multirow[t]{2}{*}{ Scale } & \multicolumn{2}{|c|}{ Spring semester } & \multicolumn{2}{|c|}{ Fall semester } \\
\hline & $M$ & $S D$ & $M$ & $S D$ \\
\hline \multicolumn{5}{|l|}{ ME } \\
\hline $\mathrm{T}$ & 47.68 & 14.82 & 56.57 & 11.28 \\
\hline $\mathrm{C}$ & 52.04 & 12.97 & 59.92 & 15.29 \\
\hline \multicolumn{5}{|l|}{ VE } \\
\hline $\mathrm{T}$ & 38.60 & 16.01 & 45.68 & 16.79 \\
\hline $\mathrm{C}$ & 41.69 & 12.97 & 48.15 & 17.08 \\
\hline \multicolumn{5}{|l|}{ SP } \\
\hline $\mathrm{T}$ & 45.27 & 16.24 & 49.13 & 15.99 \\
\hline $\mathrm{C}$ & 48.65 & 13.20 & 54.36 & 17.63 \\
\hline \multicolumn{5}{|l|}{ PR } \\
\hline $\mathrm{T}$ & 39.27 & 15.41 & 44.77 & 15.13 \\
\hline $\mathrm{C}$ & 46.17 & 18.93 & 50.46 & 15.90 \\
\hline
\end{tabular}

Note . ME = Mastery Experience; $\mathrm{VE}=$ Vicarious Experience; $\mathrm{SP}=$ Social Persuasions; $\mathrm{PR}=$ Physiological Reactions; $\mathrm{T}=$ Treatment group; $\mathrm{C}=$ Contrast group .

\section{Paired-Samples $t$ Tests}

A paired-samples $t$ test was used to determine whether there were statistically significant differences between spring and fall semester mean scores for each scale for both groups. Three outliers were detected that were more than 1.5 box-lengths from the edge of a box in a box-plot. Inspection of their values did not reveal them to be extreme and thus they were kept in the analyses. The assumption of normality was not violated, as assessed by Shapiro-Wilk's test (for ME, VE, SP, and PR, respectively, $p=.478, .092, .123$, and .540 for the contrast group and $p=.560, .722, .271$, and .576 for the treatment group).

For both groups, analyses revealed increased ME scores at the statistically significant level, with an increase of $M=6.33(S E=2.52), t(38)=2.52, p=$ $.016, d=.40$ for the contrast group and $M=8.89,(S E=2.52) t(43)=3.24, p$ $=.002, d=.50$ for the treatment group. 
For the treatment group, analyses revealed increased VE scores at the statistically significant level, with an increase of $M=7.05$ (SE $=3.13), t(43)$ $=2.25, p=.030, d=.34$.

In other words, both contrast and treatment group scores for ME increased significantly over the course of the year, whereas only the treatment group scores for VE did the same. This suggests that students feel like they learn from each other's mistakes and successes, a situation more conducive to the CL environment of the treatment group than the teacher-centred environment of the contrast group.

\section{One-Way ANCOVA}

A one-way ANCOVA was run to determine the statistical significance of mean score increases after controlling for spring semester (pretest) mean scores for each scale.

There was a linear relationship between spring and fall semester scale scores for both groups, as assessed by visual inspection of scatterplots. There was homogeneity of regression slopes as the interaction term was not statistically significant, $F(1,79)=3.927, p=.051 ; F(1,79)=.122, p=.728$; $F(81,79)=.220, p=.640$; and $F(1,79)=.169, p=.682$ for ME, VE, SP, and $\mathrm{PR}$, respectively. Standardised residuals for the overall model and for each scale were normally distributed, as assessed by Shapiro-Wilk's test ( $p>$ $.05)$. There was homoscedasticity and homogeneity of variances as assessed by visual inspection of scatter plots and Levene's test of homogeneity of variance ( $p=.060, .724, .520$, and .763 for ME, VE, SP, and PR, respectively). There were no outliers in the data, as assessed by observing no cases with standardised residuals greater than \pm 3 standard deviations. Adjusted means are presented in Table 2 below.

After adjustment for spring semester mean scores, no statistically significant difference in fall semester mean scores between groups was found for any scales, $F(1,80)=.538, p=.465$, partial $\eta^{2}=.007 ; F(1,80)=.184, p=$ $.669, \mathrm{\eta}^{2}=.002 ; F(1,80)=1.28, p=.261, \mathrm{y}^{2}=.016 ; F(1,80)=1.428, p=.236$, $\eta^{2}=.018$ for ME, VE, SP, and PR, respectively. As no statistically significant difference in fall semester scores was found between groups for all scales, post hoc analyses were not run.

To summarise, paired-samples $t$ tests revealed both groups showed an increase in scores for ME at the statistically significant level, yet only the treatment group showed the same for VE, supporting the hypothesis that employing CL strategies can improve SE. One-way ANCOVA tests showed no 
such statistical significance, meaning CL strategies may not contribute to L2 SE improvements.

Table 2. Adjusted and Unadjusted Means and Variability for Fall Semester Scale Scores with Spring Semester Scale Scores as a Covariate

\begin{tabular}{|c|c|c|c|c|}
\hline \multirow[t]{2}{*}{ Scale } & \multicolumn{2}{|c|}{ Unadjusted } & \multicolumn{2}{|c|}{ Adjusted } \\
\hline & $M$ & $S D$ & $M$ & $S E$ \\
\hline \multicolumn{5}{|l|}{$\mathrm{ME}$} \\
\hline $\mathrm{T}$ & 56.57 & 11.28 & 57.13 & 2.00 \\
\hline $\mathrm{C}$ & 59.92 & 15.29 & 59.29 & 2.12 \\
\hline \multicolumn{5}{|l|}{ VE } \\
\hline $\mathrm{T}$ & 45.68 & 16.79 & 46.09 & 2.56 \\
\hline $\mathrm{C}$ & 48.15 & 17.08 & 47.70 & 2.72 \\
\hline \multicolumn{5}{|l|}{ SP } \\
\hline $\mathrm{T}$ & 49.13 & 15.99 & 49.61 & 2.53 \\
\hline $\mathrm{C}$ & 54.36 & 17.63 & 53.83 & 2.69 \\
\hline \multicolumn{5}{|l|}{ PR } \\
\hline $\mathrm{T}$ & 44.77 & 15.13 & 45.46 & 2.34 \\
\hline $\mathrm{C}$ & 50.46 & 15.90 & 49.68 & 2.52 \\
\hline
\end{tabular}

Note . ME = Mastery Experience; VE = Vicarious Experience; SP = Social Persuasions; $\mathrm{PR}=$ Physiological Reactions; $\mathrm{T}=$ Treatment group, $\mathrm{C}=$ Contrast group.

\section{Qualitative Data Analysis}

The interview data confirmed that, as a result of the treatment learning settings, participants perceived their SE to have positively increased. Despite this, the qualitative data revealed that participants were unable to agree on which variable within the learning setting was responsible for this SE increase. Some participant responses reflect a reinforced belief of self by experiencing measurable levels of improvement. However, others reported that, although they perceived an increase in language ability (mastery experience), such gains were exclusive to an educational setting and not applicable outside the classroom. 
Excerpt 1: Treatment Group: Self- Efficacy

1 T1: Well, we can speak in the class, but because there 2 is no opportunity for us to speak English in our normal lives, I don't know what my real speaking ability level is.

5 T3: But, we don't have any confidence outside of the class. If I try to use English somewhere else, I don't have any confidence, so I can't say that I've improved.

In addition, data reflected that group interaction is possibly a key element in fostering positive changes to SE. The participants from the contrast group expressed an absence of both (a) social connection between classmates and (b) positivity about their learning experience.

Excerpt 2: Contrast Group: Self- Efficacy

1 C5: Support? I've never received that kind of support 2 before. Occasionally I've been corrected if I use 3 the wrong vocabulary, but I didn't feel like it 4 helped me improve.

5 C6: I've never received that kind of support before, so 6 I don't have a reply for that kind of situation.

7 C7: Rather than support, I've had help looking up words 8 in the dictionary.

9 C8: I received support, rather than given support. I 10 didn't feel that I improved.

In contrast, the treatment group participants reported that their group dynamic facilitated language acquisition by supporting individuals to freely express themselves, increasing intrinsic motivation.

\section{Excerpt 3: Treatment Group: Self- Efficacy}

1 T7: I didn't have an opportunity to speak in English to other people, so when I have a conversation in English, 
3 my English ability has improved.

4 T8: When I studied English in high school, I had to

5 memorise words or read sentences by myself. But during

6 this year, I had many more opportunities to speak to

7 other people, and my speaking skills have

8 improved.

Although many of the treatment group participants reported some degree of increase in SE, few of them attributed this increase to the CL process. Analysis revealed that those particular participants were inclined to credit any perceived SE increase to the research process required for task-based assignments, rather than the cooperative process that coordinated group effort. Some participants expressed a view that the factors of learner autonomy and self-directed research had a greater impact on SE than the cooperative aspects of group interaction. Some sample responses even identified the cooperative group process as a source of learner anxiety.

Excerpt 4: Treatment Group: Purpose of Learning

1 T3: I'd listen to others speak in English and think "That's awesome!". Then I would start to compare myself to other students and think "Even though they can do that, I wonder what I could do?", and it would make me anxious.

6 T4: Especially, when I heard the people who would go before me, I would think "That's awesome!" Compared to their English, I thought that my [language] level was really 9 low.

Excerpt 5: Treatment Group: Purpose of Learning

1 IR: Even though you thought, "Wow!", how did it make you 2 feel about your own ability?

3 T7: I thought, "That sucks!" because it made me feel like 4 I wasn't good at English. It made me feel like I had 5 to study more. 
6 T5: When other groups were making great presentations
$7 \quad$ and other things, I thought that I was no good.

From the participant's responses, it could be argued that the autonomous learning environment experienced by the treatment group is responsible for the increase in SE, rather than the CL approach. However, such an argument could be misleading as it would ignore established sociocultural attitudes towards educational approaches, discussed earlier in this paper. Therefore, participant rejection of the influence of CL could be viewed as preexisting participant bias.

Interview data identified key elements that indicate participants from both groups lack positive images of self, low SE, and a high degree of learner anxiety. However, the data also revealed that although participants report an increase in certain aspects of SE, there was no consensus on what classroom factor was responsible for the increase. In fact, it is difficult to determine whether participant rejection of the cooperative approach reflected opinions formed as a result of these classroom experiences, or whether they are rooted in cultural attitudes shared amongst a wider learner community. It is possible that the absence of English communication in the day-to-day life of most Japanese people, and its perceived status in Japan as a foreign language, rather than an L2 (Adachi, 2015; Amburgey, 2015; Maftoon \& Ziafar, 2013), could help explain this collective response by participants.

\section{Implications and Conclusions}

The findings of this study make two noteworthy contributions to furthering our understanding of SE research. First, the results supported the hypothesis that a CL environment can positively increase student SE within a language learning context. Second, the positive statistical variance in SE level shown in the findings validates the argument for the CLT approach being wholly applicable to a non-Western EFL teaching. CL, which has been shown to inadvertently promote autonomous aspects, appears to have no detrimental effects on students' perceptions of their ability. Rather, this study demonstrates that these methods have a significant positive effect on student SE, particularly in terms of VE. Qualitative data analysis revealed that, although not clearly perceived by the participants, group-work strategies appeared to enhance ME through cooperative approaches fostered through developing a student-centered class dynamic. Although shown to fuel aspects of learner anxiety, VE was shown to influence participants' intrinsic motivation, which inspired participants to further their skill and influence perceived SE levels. 
There are numerous avenues with which to improve and continue this investigation. First, involving a larger sample size of participants in order to gain a more accurate perception of changes in student SE could benefit research outcomes. In addition, following participants for the full 2 years of their course could offer further insight into whether changes in SE remain consistent. Regarding qualitative research, some of the questions used in the interview could be perceived as misleading due to their phrasing. Future interviews should include an open-ended question design to encourage greater independence and depth of responses from participants. Furthermore, investigating a range of additional variables (such as gender, age, past experiences of English language learning, and major) would provide a richer insight into possible explanations for changes in SE.

The results of this study have potential far-reaching applications for language teaching methodology within the EFL context. Communicative learning approaches have shown to enable increased learner SE, which has the potential to improve learner output and possibly enhance English communication to meet CLT standards of contemporary language education environments. Although this study was conducted within the Japanese context, the implications of these findings are arguably not limited to the cultural EFL learning experiences of Japan. Sociocultural beliefs rooted in philosophical thought that place value on power distance, collectivism, and uncertainty avoidance are arguably not exclusive to Japan and are shared by other cultures around the world. By this reasoning, a rational argument could be made to assert that these methods, applied to comparable contexts elsewhere, could result in similar learner outcomes.

\section{Acknowledgments}

We would like to thank Dr. John Eidswick, Dr. Michiko Yamada, Dr. Yoshihito Kamakura, and Dr. Lachlan Jackson for their encouragement and advice throughout the process.

James Saunders-Wyndham is a Practical English Instructor in the Institute of General Education, Kyoto Sangyo University, Japan. His research interests include Japanese ICT education and teacher efficacy.

Eleanor Smith is an Assistant Professor in the Faculty of International Communication, Aichi University, Japan. Her research interests include intercultural communication competency and cultural studies. 


\section{References}

Adachi, R. (2015). Motivation and communicative attitudes among Japanese EFL pupils. Indonesian Journal of Applied Linguistics, 5(1), 1-10. https://doi. org/10.17509/ijal.v5i1.824

Amburgey, B. H. (2015). Language learning motivation: A comparative study of Danish and Japanese university students. Hitotsubashi Journal of Arts and Sciences, 56(1), 29-41. https://doi.org/10.15057/27654

Anyadubalu, C. C. (2010). Self-efficacy, anxiety, and performance in the English language among middle-school students in English language program in Satri Si Suriyothai School, Bangkok. World Academy of Science, Engineering and Technology, 39, 193-198. http://citeseerx.ist.psu.edu/viewdoc/download?doi=10.1.1.3 09.5940\&rep=rep1\&type=pdf

Bandura, A. (1977). Self-efficacy: Toward a unifying theory of behavioral change. Psychological Review, 84(2), 191-215. https://doi.org/10.1037/0033295X.84.2.191

Bandura, A. (1997). Self-efficacy: The exercise of control. W. H. Freeman and Company.

Bandura, A. (2006). Guide for constructing self-efficacy scales. In F. Pajares \& T. C. Urdan (Eds.) Self-efficacy beliefs of adolescents (Vol. 5, pp. 307-337). Information Age Publishing.

Bandura, A., \& Schunk, D. H. (1981). Cultivating competence, self-efficacy, and intrinsic interest through proximal self-motivation. Journal of Personality and Social Psychology, 41(3), 586-598. https://doi.org/10.1037/00223514.41.3.586

Bergiel, E. B., Bergiel, B. J., \& Upson, J. W. (2012). Revisiting Hofstede's dimensions: Examining the cultural convergence of the United States and Japan. American Journal of Management, 12(1), 69-79. http://www.na-businesspress.com/AJM/ BergielEB_Web12_1_.pdf

Bjørnebekk, G., Diseth, Å., \& Ulriksen, R. (2013). Achievement motives, self-efficacy, achievement goals, and academic achievement at multiple stages of education: A longitudinal analysis. Psychological Reports, 112(3), 771-787. https://doi. org/10.2466/14.09.PR0.112.3.771-787

Chips, B. (1993). Using cooperative learning at the secondary level. In D. D. Holt (Ed.). Cooperative learning: A response to linguistic and cultural diversity (pp. 81-92). Delta Systems and Center for Applied Linguistics.

Coronado-Aliegro J. (2007). Enhancing learner self-efficacy through continuous self-assessment: Implications for the foreign language classroom. In A. J. Moeller (Ed.), Learning Languages in a Digital World: Selected Papers from the 2007 Central States Conference (pp. 127-141). RMT. https://digitalcommons.unl. edu/cgi/viewcontent.cgi? article $=1300 \&$ context=teachlearnfacpub\# page $=139$ 
Diseth, Å. (2011). Self-efficacy, goal orientations and learning strategies as mediators between preceding and subsequent academic achievement. Learning and Individual Differences, 21(2), 191-195. https://doi.org/10.1016/j. lindif.2011.01.003

Dörnyei, Z. (2007). Research methods in applied linguistics: Quantitative, qualitative, and mixed methodologies. Oxford University Press.

Hofstede, G., Hofstede G. J., \& Minkov, M. (2010). Cultures and organizations: Software of the mind (3rd ed.). McGraw-Hill.

Hsieh, P.-H. P., \& Schallert, D. L. (2008). Implications from self-efficacy and attribution theories for an understanding of undergraduates' motivation in a foreign language course. Contemporary Educational Psychology, 33(4), 513-532. https://doi.org/10.1016/j.cedpsych.2008.01.003

Johnson, D. (1979). Educational psychology. Prentice Hall.

Johnson, D. W., \& Johnson, R. T. (2005). New developments in social interdependence theory. Genetic, Social, and General Psychology Monographs, 131(4), 285-358. https://doi.org/10.3200/MONO.131.4.285-358

Johnson, D. W., \& Johnson, R. T. (2009). An educational psychology success story: Social interdependence theory and cooperative learning. Educational Researcher, 38(5), 365-379. https://doi.org/10.3102/0013189X09339057

Johnson, D. W., \& Johnson, R. T. (2014). Cooperative learning in 21st century. Anales de Psicología, 30(3), 841-851. http://dx.doi.org/10.6018/analesps.30.3.201241

Kagan, S. (1989). The structural approach to cooperative learning. Educational Leader, 47(4), 12-15.

Kagan, S., \& McGroarty, M. (1993). Principles of cooperative learning for language and content gains. In D. D. Holt (Ed.). Cooperative learning: A response to linguistic and cultural diversity (pp. 47-64). Delta Systems and Center for Applied Linguistics.

Kimura, Y., Nakata, Y., \& Okumura, T. (2001). Language learning motivation of EFL learners in Japan-A cross-sectional analysis of various learning milieus. JALT Journal, 23(1), 47-65. https://doi.org/10.37546/JALTJJ23.1-3

Liem, A. D., Lau, S., \& Nie, Y. (2008). The role of self-efficacy, task value, and achievement goals in predicting learning strategies, task disengagement, peer relationship, and achievement outcome. Contemporary Educational Psychology, 33(4), 486-512. https://doi.org/10.1016/j.cedpsych.2007.08.001

Linnenbrink-Garcia, L., Tyson, D. F., \& Patall, E. A. (2008). When are achievement goal orientations beneficial for academic achievement? A closer look at main effects and moderating factors. Revue Internationale De Psychology Sociale, 21(1-2), 19-70. 
Madden, N. A., \& Slavin, R. E. (1983). Effect of cooperative learning on the social acceptance of mainstreamed academically handicapped students. Journal of Special Education, 17(2), 171-182. https://doi. org/10.1177/002246698301700208

Madrid, C. (1993). Using cooperative learning at the elementary level. In D. D. Holt (Ed.). Cooperative learning: A response to linguistic and cultural diversity (pp. 67-78). Delta Systems and Center for Applied Linguistics.

Maftoon, P., \& Ziafar, M. (2013). Effective factors in interactions within Japanese EFL classrooms. The Clearing House: A Journal of Educational Strategies, Issues and Ideas, 86(2), 74-79. https://doi.org/10.1080/00098655.2012.748641

Magogwe, J. M., \& Oliver, R. (2007). The relationship between language learning strategies, proficiency, age and self-efficacy beliefs: A study of language learners in Botswana. System, 35(3), 338-352. https://doi.org/10.1016/j. system.2007.01.003

Ning, H., \& Hornby, G. (2014). The impact of cooperative learning on tertiary EFL learners' motivation. Educational Review, 66(1), 108-124. https://doi.org/10.10 80/00131911.2013.853169

Norem-Hebeisen, A. A., \& Johnson, D. W. (1981). The relationship between cooperative, competitive, and individualistic attitudes and differentiated aspects of self-esteem. Journal of Personality, 49(4), 415-426. https://doi. org/10.1111/j.1467-6494.1981.tb00223.x

Oickle, E. M. (1980). A comparison of individual and team learning [Doctoral dissertation, University of Maryland]. Digital Repository at the University of Maryland. https://doi.org/10.13016/M2G44HQ8C

Oxford, R. L. (2017). Teaching and researching language learning strategies: Self-regulation in context (2nd ed.). Routledge. https://doi. org/10.4324/9781315719146

Pajares, F. (2003). Self-efficacy beliefs, motivation, and achievement in writing: A review of the literature. Reading \& Writing Quarterly, 19(2), 139-158. https:// doi.org/10.1080/10573560308222

Phuong-Mai, N., Elliot, J. C., Terlouw, C., \& Pilot, A. (2009). Neocolonialism in education: Cooperative learning in an Asian context. Comparative Education, 45(1), 109-130. https://doi.org/10.1080/03050060802661428

Phuong-Mai, N., Terlouw, C., \& Pilot, A. (2005). Cooperative learning vs Confucian heritage culture's collectivism: Confrontation to reveal some cultural conflicts and mismatch. Asia Europe Journal, 3(3), 403-419. https://doi.org/10.1007/ s10308-005-0008-4

Raoofi, S., Tan, H. T., \& Chan, S. H. (2012). Self-efficacy in second/foreign language learning contexts. English Language Teaching, 5(11), 60-73. https://doi. org/10.5539/elt.v5n11p60 
Sakui, K. (2007). Classroom management in Japanese EFL classrooms. JALT Journal, 29(1), 41-58. https://doi.org/10.37546/JALTJJ29.1-2

Schunk, D. H. (1991). Self-efficacy and academic motivation. Educational Psychologist, 26(3-4), 207-231. https://doi.org/10.1080/00461520.1991.9653133

Sugie, S. (1999). Cooperative learning in Japan: History and present situation of research and implementation. In D. Kluge, S. McGuire, D. Johnson, \& R. Johnson (Eds.), JALT applied materials: Cooperative learning (pp. 38-49). Japan Association for Language Teaching.

Tan, I. G. C., Sharan, S., \& Lee, C. K. E. (2007). Group investigation effects on achievement, motivation, and perceptions of students in Singapore. The Journal of Educational Research, 100(3), 142-154. https://doi.org/10.3200/ JOER.100.3.142-154

Thanh, P. T. H., Gillies, R., \& Renshaw, P. (2008). Cooperative learning (CL) and academic achievement of Asian students: A true story. International Education Studies, 1(3), 82-88. https://doi.org/10.5539/ies.v1n3p82

Tilfarlioglu, F. T., \& Ciftci, F. S. (2011). Supporting self-efficacy and learner autonomy in relation to academic success in EFL classrooms (a case study). Theory and Practice in Language Studies, 1(10), 1284-1294. https://doi.org/10.4304/ tpls.1.10.1284-1294

Ueki, M., \& Takeuchi, O. (2012). Validating the L2 motivational self system in a Japanese EFL context: The interplay of L2 motivation, L2 anxiety, self-efficacy, and the perceived amount of information. Language Education \& Technology, 49, 1-22. https://doi.org/10.24539/let.49.0_1

Williams, K. E., \& Andrade, M. R. (2008). Foreign language learning anxiety in Japanese EFL university classes: Causes, coping, and locus of control. Electronic Journal of Foreign Language Teaching, 5(2), 181-191. https://e-flt.nus.edu.sg/ v5n22008/williams.pdf

Wong. M. S.-L. (2005). Language learning strategies and language self-efficacy: Investigating the relationship in Malaysia. RELC Journal, 36(3), 245-269. https:// doi.org/10.1177/0033688205060050

Yashima, T. (2002). Willingness to communicate in a second language: The Japanese EFL context. The Modern Language Journal, 86(1), 54-66. https://doi. org/10.1111/1540-4781.00136

Yllmaz, C. (2010). The relationship between language learning strategies, gender, proficiency and self-efficacy beliefs: A study of ELT learners in Turkey. Procedia Social and Behavioral Sciences, 2, 682-687. https://doi.org/10.1016/j. sbspro.2010.03.084

Yoshida, H., Tani, S., Uchida, T., Masui, J., \& Nakayama, A. (2013). Structural analysis of anxiety in online cooperative learning. IJEEEE, 3(5), 381-385. https://doi. org/10.7763/IJEEEE.2013.V3.263 
Zheng, D., Young, M. F., Brewer, R. A., \& Wagner, M. (2009). Attitude and self-efficacy change: English language learning in virtual worlds. CALICO Journal, 27(1), 205-231. https://doi.org/10.11139/cj.27.1.205-231

Zimmerman, B. J., \& Cleary, T. J. (2005). Adolescents' development of personal agency: The role of self-regulatory skill. In F. Pajares \& T. Urdan (Eds.), Selfefficacy beliefs of adolescents (pp. 45-69). Information Age Publishing.

\section{Appendix A}

\section{Participant Questionnaire}

1. Some of the following situations can be difficult for some students to deal with when speaking, listening, and writing only in English. Do you believe that your English ability can help you in the following situations? In the blank spaces below, please rate how certain you are of your English abilities in the following situations.

- Understanding the teacher

- Replying to the teacher's question

- Completing an assignment on time.

- Brainstorming ideas with peers.

- Making a presentation in front of the class by yourself.

- Making a presentation in front of the class in a group.

- Using new grammar just after you learnt it in class.

- Using new vocabulary in conversation.

- Speaking to classmates

- Doing well on the final exam.

2. When you see your classmates do the following activities, how does it make you feel about your own English abilities? Do you feel that you can do the same as your friends? In the blank spaces below, please rate how certain you are of your English abilities in the following situations.

- Classmates using difficult words.

- Classmates having an English conversation.

- Classmates making a good class presentation.

- Classmates talking about foreign culture.

- Classmates being confident about communicating with the teacher.

- Classmates always completing their homework.

- Classmates answering the teacher's questions. 
- A student demonstrating new grammar to the class.

- Classmates being fast to respond with ideas.

- Classmates improving their test scores.

3. How do you feel about your ability to respond in English in the following situations? In the blank spaces below, please rate how certain you are of your English abilities in the following situations.

- Being praised by the teacher for my progress in class.

- Talking to the teacher one-on-one.

- Being asked for help by my classmates in class.

- Receiving support from classmates.

- Doing group work with students I don't know.

4. Using English can make some Japanese people very nervous. In the following situations, do you believe that you are able to remain calm in front of your classmates? In the blank spaces below, please rate how certain you are of your ability to stay calm when using English in the following situations in front of your classmates.

- Expressing my ideas and opinions in class.

- Answering the teacher's questions.

- Using new grammar.

- Understanding difficult instructions.

- Making mistakes when the class is watching.

\section{Appendix B}

\section{Interview questions}

1. Do you believe that your ability to present your ideas to others in English improved over this school year?

2. How do you feel about your own English ability after your classmates do well in class, e.g. when they make a good presentation in front of the class?

3. When discussing foreign culture with your classmates, did it make you feel like you could improve your English ability?

4. When working with your classmates in a group, how did you feel positive about your English ability?

5. When you received support from a classmate, did you feel that your 
English ability could improve?

6. Do you feel that your ability to express your own ideas in English class improved over this past year?

7. When you learnt new grammar this year, did you feel that you were able to use it in conversation or in a presentation? 